\title{
ROW AND PLANT SPACING EFFECTS ON AGRONOMIC PERFORMANCE OF SUNFLOWER IN WARM AND SEMI-COLD AREAS OF IRAN
}

\author{
Beg, A. ${ }^{1}$, Pourdad, S.S. $^{2}$, Alipour, S. $^{2}$ \\ ${ }^{1}$ ICARDA-Iran, Dry Land Agricultural Research Station, Sararood, Kermanshah \\ ${ }^{2}$ Dry Land Agricultural Research Station, Sararood, Kermanshah
}

Received: December 11, 2006 Accepted: September 15, 2007

\section{SUMMARY}

\begin{abstract}
Sunflower (Helianthus annuus L.) is an important oilseed crop. It was grown on more than 20 million hectares in the world in 1997, of which 60,000 ha were in Iran. There is a potential for substantial increase in sunflower acreage and production on dry land in Iran by applying optimum management practices. Two important management considerations are selecting row and plant spacings able to provide adequate plant density that will maximize seed yields and minimize seeding costs. This study conducted in 1998 investigated the effect of plant density $(38,000$ to $100,000 \mathrm{pl} / \mathrm{ha})$ in combination with row $(50$ and $75 \mathrm{~cm})$ and plant spacing $(20,25,30,35 \mathrm{~cm})$ on agronomic traits of two open pollinated sunflower cultivars, Progress and Record, grown under rain-fed conditions at two dry land research stations, one located at Gachsaran (a warm region) and another in Sararood (a semi-cold area of Iran). Sowing was performed on moist soil after effective rains in early spring. Higher plant populations produced higher yield compared with lower populations in both locations. Average yield was higher at Gachsaran than at Sararood, this can be due to varietal differences. The rainfall during the trial year was $854.6 \mathrm{~mm}$ at Gachsaran and $613 \mathrm{~mm}$ at Sararood.
\end{abstract}

Key words: sunflower (Helianthus annuus L.), agronomic traits, climatic conditions

\section{INTRODUCTION}

Sunflower is an important crop in West Asia and North Africa. World acreage in 1997 was 20.24 million hectares, with $5 \%$ of the acreage and production being located in WANA (FAO, 1997). Turkey, Morocco, Pakistan, Iran, Iraq and Sudan were the leading producers in WANA. In Iran, the acreage was 60,000 ha and the average yield about $850 \mathrm{~kg} / \mathrm{ha}$. The oil type sunflower is grown in Iran mostly in the north of the country, typically under irrigation although this area receives high rainfall. There is a need to standardize sunflower production practices for the different climatic conditions in the country. Plant population based on row and plant spacing 
is a major part of agronomic practices, inter alia, leading to optimum productivity. Weiss (1983) reported from literature that in Australia plant populations above 50,000 plants/ha, when used under dry land conditions, reduced both sunflower yield and oil percentage. In North Dakota (Zubriski and Zimmerman, 1974), it was found that increasing population from 36,000 to 72,090 plants/ha significantly increased seed and oil yields. However, Miller and Fick (1978), using a similar range of plant populations, reported that seed yields were not affected by increase in plant population. Robinson et al. (1980) observed that minimum plant population needed for maximum yield in Minnesota varied among locations from 25,000 to 62,000 plants/ha. Variation in optimum plant population among locations was attributed to differences in soil type, precipitation and temperatures. In the same study, the authors reported that high plant population increased oil percentage and test weight, but reduced head diameter. Majid and Schneiter (1987) reported that increasing plant population from 66,717 to 101,311 plants/ha had no significant affect on grain yield and seed number per head but it reduced 1000-seed weight by $5 \%$ because some plants perished during the growing season at higher population. Most of these studies were conducted using hybrid cultivars in temperate regions. Pala (1990) at ICARDA, Syria, found that average yields of two cultivars increased when plant population was increased from 10,000 plants/ha to 20,000/ha, however, further increases to 30,000 and 40,000 plants/ha did not affect seed yield. At the same station, Beg et al. (2003) found that high populations, from 80,000 to 100,000 plants, produced significantly high yields. Agronomic practices in addition to high yielding varieties are the two most important items for higher productivity of the sunflower crop. Among the agronomic practices, optimum plant population plays a major role. This experiment was conducted in order to determine optimum row and plant spacings for higher yields of dry-land sunflower grown in warm and semi-cold regions of Iran.

\section{MATERIALS AND METHODS}

The trial was conducted at Dry Land Agricultural Research Stations Gachsaran in a warm part of the country and in Sararood located in a semi-cold region. The rainfall seasons and patterns are similar in the two locations. Row spacing treatments were 50 and $75 \mathrm{~cm}$, plant to plant distance treatments were 20,25, 30 and $35 \mathrm{~cm}$. The combining of row and plant spacings resulted in plant populations from 38,000 to 100,000 plants per hectare.

For each plant spacing, the lower row spacing (50 $\mathrm{cm}$ ) has a larger population than the higher row spacing $(75 \mathrm{~cm})$. The varieties employed were 'Progress' at Gachsaran and 'Record' at Sararood. Both are high-

\begin{tabular}{cc}
\hline $\begin{array}{c}\text { Row }+ \\
\text { plant spacing }\end{array}$ & $\begin{array}{c}\text { Plant } \\
\text { population/ha }\end{array}$ \\
\hline $50-20$ & 100,000 \\
$50-25$ & 80,000 \\
$50-30$ & 67,000 \\
$50-35$ & 57,000 \\
$75-20$ & 67,000 \\
$75-25$ & 53,000 \\
$75-30$ & 45,000 \\
$75-35$ & 38,000 \\
\hline
\end{tabular}


yielding open pollinated varieties. Record is a famous commercial variety from Romania and Progress is from Russia. These varieties have produced high yields at these stations in evaluation tests.

\section{RESULTS AND DISCUSSION}

Data from both stations are summarized in Table 1. The highest yield of 1,072 $\mathrm{kg} / \mathrm{ha}$ was obtained at Gachsaran from the combination of $50 \mathrm{~cm}$ row spacing and $20 \mathrm{~cm}$ plant spacing, which produced the highest plant population of 100,000 plants/ha. The second highest yield of $972 \mathrm{~kg} /$ ha was from the combination $75 \mathrm{~cm}$ $\mathrm{RS}+20 \mathrm{~cm}$ PS and the third highest yield of $962 \mathrm{~kg} / \mathrm{ha}$ was from the combination $50 \mathrm{~cm} \mathrm{RS}+35 \mathrm{~cm}$ PS.

Table 1: Row and plant spacing effect on agronomic traits of sunflower

\begin{tabular}{|c|c|c|c|c|c|c|c|c|}
\hline $\begin{array}{l}\text { Row/pl } \\
\text { spacing }\end{array}$ & $\begin{array}{c}\text { Plant } \\
\text { population }\end{array}$ & $\begin{array}{c}\text { Plant } \\
\text { height }\end{array}$ & $\begin{array}{c}\text { Head } \\
\text { diameter }\end{array}$ & $\begin{array}{c}\text { Stem } \\
\text { diameter }\end{array}$ & $\begin{array}{l}\text { Days to } \\
\text { flowering }\end{array}$ & $\begin{array}{l}\text { Days to } \\
\text { maturity }\end{array}$ & $\begin{array}{c}1000- \\
\text { seed wt }\end{array}$ & Yield \\
\hline (cm) & (per/ha) & $(\mathrm{cm})$ & $(\mathrm{cm})$ & $(\mathrm{mm})$ & (day) & (day) & (g) & (kg/ha) \\
\hline \multicolumn{9}{|l|}{ Gachsaran } \\
\hline $50-20$ & 100,000 & 115 & 12 & 8.7 & 103 & 132 & 39 & 1072 \\
\hline $50-25$ & 80,000 & 106 & 11 & 10.3 & 106 & 134 & 39 & 828 \\
\hline $50-30$ & 67,000 & 104 & 11 & 10.9 & 106 & 134 & 46 & 655 \\
\hline $50-35$ & 57,000 & 112 & 14 & 10.1 & 105 & 132 & 47 & 962 \\
\hline $75-20$ & 67,000 & 114 & 14 & 10.8 & 105 & 131 & 49 & 972 \\
\hline $75-25$ & 53,000 & 106 & 11 & 11.1 & 105 & 132 & 46 & 567 \\
\hline $75-30$ & 45,000 & 110 & 14 & 12.8 & 105 & 131 & 44 & 568 \\
\hline $75-35$ & 38,000 & 114 & 13 & 10.3 & 107 & 134 & 50 & 536 \\
\hline CV (\%) & & & & & & & & 18.0 \\
\hline LSD (\%) & & & & & & & & 203 \\
\hline \multicolumn{9}{|l|}{ Sararood } \\
\hline $50-20$ & 100,000 & 125 & 8 & 14 & 107 & 135 & 35 & 491 \\
\hline $50-25$ & 80,000 & 129 & 10 & 16 & 106 & 136 & 39 & 592 \\
\hline $50-30$ & 67,000 & 119 & 11 & 15 & 107 & 137 & 40 & 735 \\
\hline $50-35$ & 57,000 & 131 & 11 & 15 & 106 & 136 & 42 & 699 \\
\hline $75-20$ & 67,000 & 128 & 9 & 15 & 106 & 136 & 36 & 786 \\
\hline $75-25$ & 53,000 & 127 & 10 & 20 & 105 & 135 & 35 & 681 \\
\hline $75-30$ & 45,000 & 126 & 10 & 14 & 107 & 137 & 47 & 596 \\
\hline $75-35$ & 38,000 & 133 & 12 & 17 & 106 & 136 & 40 & 539 \\
\hline CV (\%) & & & & & & & & 18.1 \\
\hline LSD (at $5 \%$ ) & & & & & & & & 169 \\
\hline
\end{tabular}

There was a linear decrease in yield in the treatments with the larger row spacing and increased plant spacings. These results are in agreement with the results presented recently by Beg et al. (2003). At Sararood, even though the results were not as strikingly in favor of higher populations as it was in the warmer location of 
Gachsaran, the populations of 67,000/ha from the combinations $75 \mathrm{~cm}$ RS $+20 \mathrm{~cm}$ PS and $50 \mathrm{~cm} \mathrm{RS}+30 \mathrm{~cm}$ PS produced the highest yields of $786 \mathrm{~kg} / \mathrm{ha}$ and $735 \mathrm{~kg} /$ ha, respectively, followed by the population of 57,000 plants $/$ ha $(50 \mathrm{~cm} \mathrm{RS}+35 \mathrm{~cm}$ PS) which gave $699 \mathrm{~kg} / \mathrm{ha}$. The previous two plant populations/ha are also considered as high populations. A lower average temperature in early spring might have resulted in lower yields at Sararood as compared with the first station.

\section{CONCLUSIONS}

This one-year experiment conducted in two climatically different locations suggests that the narrow row spacing $(20 \mathrm{~cm})$ coupled with low plant spacings resulting in high plant populations of about $100000 \mathrm{pl} /$ ha can provide an economical sunflower yield under rain-fed conditions in dry and warm regions of Iran. In semi-cold regions, plant populations from 57,000 to 67,000 plants/ha seem to be adequate. These results agree with the results obtained by different workers on dry land and in similar climates. The moisture provision in both the warm and the semi-cold location (400 $\mathrm{mm}$ and above) was adequate to produce an economical yield of the sunflower crop. Data also suggest that high yielding varieties should be selected for each type of climate. If followed, these results may enhance the productivity of sunflower grown under dry land conditions.

\section{REFERENCES}

Beg, A., Pala, M. and Poudad, S.S., 2003. Sunflower Production as Influenced by Plant Density and Row Spacing on Dry Land. Proceeding of International Dry Land Conference held at Tehran Iran. September 2003 (in press).

FAO, 1997. Production Yearbook.

Majid, H.R., and Schneiter, A.A., 1987. Yield and quality of semidwarf and standard height sunflower hybrids grown at five plant populations. Agron. J. 79: 681-684.

Miller, J.F. and Fick, G.N., 1978. Influence of plant population on performance of sunflower hybrids. Can. J. Plant Sci. 58: 597-600.

Pala, M., 1992. Oilseeds. Annual Report, Farm Resource Management Programme. ICARDA. Robinson, R.G., Ford, J.H., Lueschen, W.E., Rabas, D.L., Smith, L.J., Warnes, D.D. and Wiersma, J.V., 1980. Response of sunflower to plant population. Agron. J. 72: 860-871.

Zubriski, J.C., and Zimmerman, D.C., 1974. Effects of nitrogen, phosphorus and plant density on sunflower. Agron. J. 66: 798-801.

Weiss, E.A., 1983. Tropical Oilseed Crops. Longmans, New York.

\section{INFLUENCIA DE LAS DISTANCIAS ENTRE LAS FILAS Y LAS \\ PLANTAS EN LA FILA EN LAS PROPIEDADES AGRONÓMICAS DE GIRASOL CULTIVADO EN LAS REGIONES CÁLIDAS Y MODERADAMENTE FRÍAS DE IRÁN}

RESUMEN

El girasol (Helianthus annuus L.) es un cultivo oleaginoso importante. En el año 1997 se cultivaba en más de 20 millones de hectáreas en el mundo, de los cuales 60.000 ha han sido en Irán. Existe el potencial para el aumento significativo de las superficies y producción de girasol en las superficies no irriga- 
das en Irán, en el caso de aplicar las óptimas medidas agrotécnicas. La elección de las distancias entre filas y en la fila tiene dos parámetros importantes que garantizan una adecuada densidad de plantaciones, incrementan el rendimiento de girasol y reducen los costos de siembra. La investigación llevada a cabo en el año 1998, se dedicaba a la influencia de la densidad de las plantas $(38,000$ hasta 100,000 plantas/ha) en combinación con la distancia entre filas $(50$ y $75 \mathrm{~cm}$ ) y las plantas en la fila $(20,25,30,35 \mathrm{~cm}$ ) en las propiedades agronómicas de dos variedades de girasol, Progres y Rekord, que se cultivaban en las condiciones de labranza seca en dos estaciones de investigación - una ubicada en Gahsaran (región cálida), y otra ubicada en Sararud (la región moderadamente fría de Irán). La siembra fue efectuada en el suelo húmedo de mayores lluvias, caídas en la temprana primavera. El número de plantas incrementado dio mayor rendimiento del número plantas menor en ambas localidades. El rendimiento promedio fue mayor en Gahsaran que en Sararud, lo que puede ser consecuencia de las diferencias entre las variedades. El nivel de precipitaciones durante el año de investigación, fue $854.6 \mathrm{~mm}$ en Gahsaran y 613 mm en Sararud.

\title{
EFFETS DE LA DISTANCE ENTRE LES RANGS ET ENTRE LES PLANTES SUR LA PERFORMANCE AGRONOMIQUE DU TOURNESOL DANS LES RÉGIONS CHAUDES OU MODÉRÉMENT FROIDES D'IRAN
}

\author{
RÉSUMÉ
}

Le tournesol (Helianthus annuus L.) est une importante plante oléagineuse. En 1997, il était cultivé sur plus de 20 millions d'hectares dans le monde, dont 60,000 en Iran. La surface de culture et la production pourraient être augmentés de façon substantielle si on appliquait des mesures agrotechniques optimales. Le choix de la distance entre les rangs et celui de la distance dans les rangs sont deux paramètres importants qui assurent une densité adéquate de la culture, augmentent le rendement du tournesol et diminuent le coût des semailles. Cette étude menée en 1998 avait pour objet l'effet de la densité des plantes $(38,000$ à 100,000 plantes/ha) associée à l'espace entre les rangs (50 et $75 \mathrm{~cm}$ ) et entre les plantes $(20,25,30,35 \mathrm{~cm}$ ) sur les caractéristiques agronomiques de deux cultivars de tournesol, Progress et Record, cultivés dans des conditions de non-irrigation à deux stations de recherche, l'une située dans la région de Gachsaran (région chaude) et l'autre dans celle de Sararood (région modérément froide d'Iran). Les semailles ont été faites sur un sol humide après des pluies abondantes tôt au printemps. Dans les deux localités, les populations plus nombreuses ont donné un plus grand rendement que les populations moins abondantes. Le rendement moyen a été plus élevé dans la région de Gachsaran que dans celle de Sararood ce qui peut être la conséquence de la différence entre les variétés. Le niveau de précipitations au cours de l'année de l'expérience a été de 854,6 à Gachsaran et de $613 \mathrm{~mm}$ à Sararood. 
